\title{
Synthesis of New7-ethyl-4-methyl-2-Quinolone Derivatives
}

\author{
Luma S. Ahamed ${ }^{1}$, Rana Abid Ali ${ }^{1}$, Rana S.Ahmed ${ }^{2}$, Mohammed R. Ahamad ${ }^{1}$ and \\ Redha I. Al-Bayati ${ }^{3}$ \\ ${ }^{1}$ Department of Chemistry, College of Science, University of Baghdad, Baghdad, Iraq \\ ${ }^{2}$ Department of pharmacy, Al Israa University college, Baghdad, Iraq \\ ${ }^{3}$ Department of Chemistry, College of Science, Al-Mustansirya University, Baghdad, Iraq
}

\begin{abstract} their physical properties. [DOI: 10.22401/ANJS.00.2.04]

\section{Introduction}

Quinolones (carbostyrils or 1azacoumarins) are among the most popular Nheteroaromatic compounds that are isosteric with coumarins and isomeric to 4-quinolone; these compounds would likely be potential candidates for antibacterial activity ${ }^{(1)}$, potential topoisomerase inhibitor anticancer agents $^{(2)}$ antimicrobial $^{(3),}$ anti-inflammatory ${ }^{(4)}$,
\end{abstract}

A series of new derivatives of 7-ethyl-4-methyl quinoline-2-one were synthesized, by cyclization reaction of m-ethyl phenol with ethylacetoacetate in the presence of sulfuric acid to yield 7-ethyl-4-methyl coumarin, which was chosen as the starting material and it was treated with hydrazine hydrate $80 \%$ to give a new compound 1-amino-4 methyl-7- ethyl quinoline-2(1H)-one. The later compound introduced in different synthetic methods to produce new 4-methyl-7-ethyl-2qunolone derivatives containing amide, imine, and acetylenic groups (L4-L10). Synthesized compounds were characterized by FT-IR, ${ }^{1} \mathrm{H}-\mathrm{NMR},{ }^{13} \mathrm{C}-\mathrm{NMR}$ spectra and by measuring some of

antimalarial $^{(5),}$ antifungal $^{(6)}$, antitubercular ${ }^{(7)}$, and others.

Quinolones were applied as new drugs for Alzheimer's Disease ${ }^{(8)}$, activity against Trypanosoma brucei ${ }^{(9)}$. The large number of compounds derived from quinolones with various activities pharmacological encouraging us continued preparation and find others that could serve in biological activities as shown in scheme1.

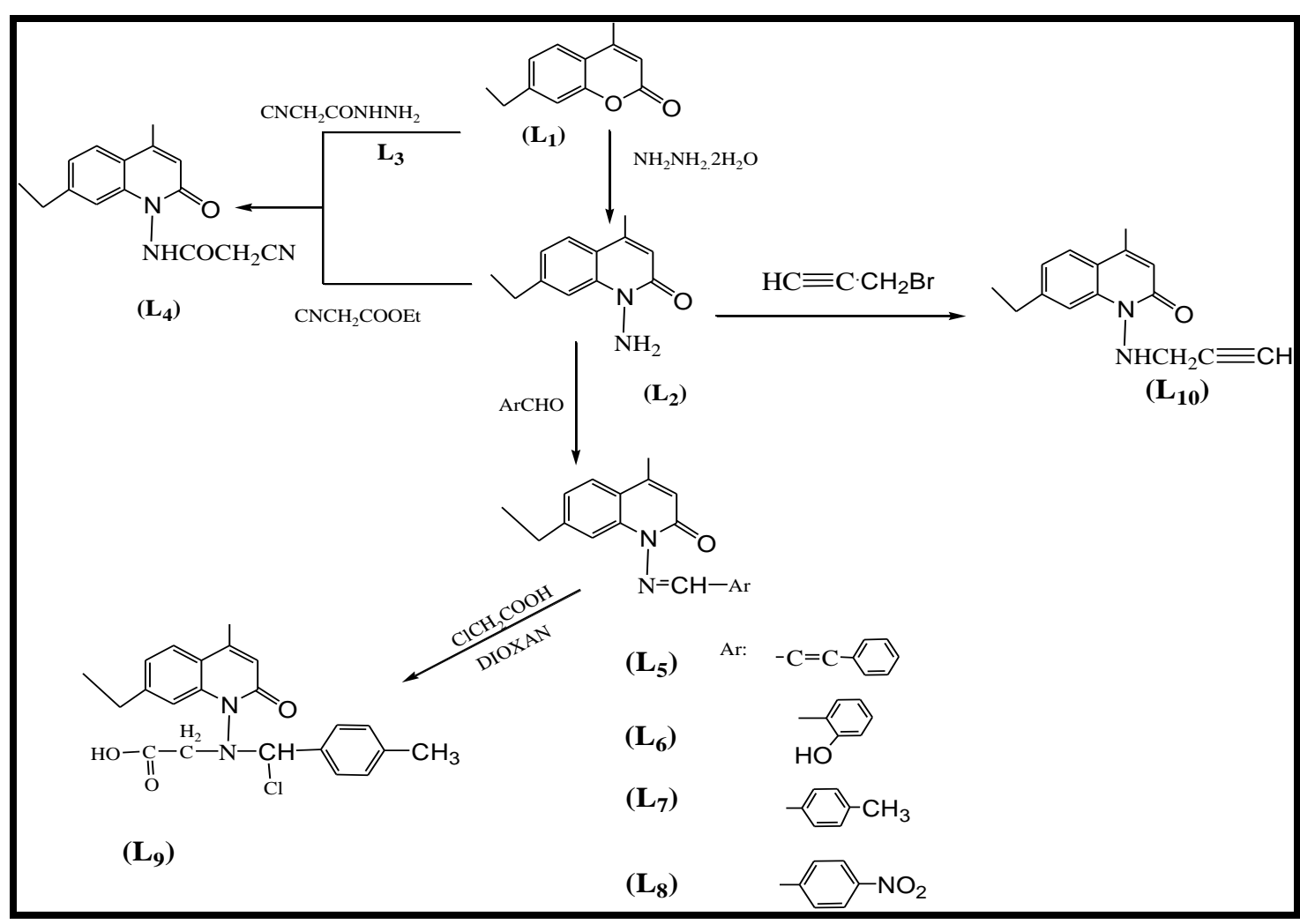

Scheme 1 Synthesis of New7-ethyl-4-methyl-2-Quinolone Derivatives. 


\section{Materials and Methods}

Instruments:

The FT-IR spectra in the range (4000400) $\mathrm{cm}^{-1}$ were recorded on a Shimadzu FTIR 8300 Spectrophotometer. 1H-NMR and 13C-NMR spectra (solvent DMSO-d6) were recorded on a Bruker-DPX $400 \mathrm{MHz}$ spectrometer with TMS as internal standard at Isfahan University. Melting points were determined on a Gallen-kamp MFB-600 melting point apparatus and were uncorrected. Analytical thin layer chromatography (TLC) in (7:3 ratio of hexane: ethyl acetate) as the mobile phase was performed on plates precoated with silica gel (Merck 60 F254, $0.25 \mathrm{~mm}$ ) and was visualized with ultraviolet light.

\section{Chemicals:}

Starting chemical compounds were obtained from BDH, Sigma Aldrich and Fluka and were used as received without further purification.

\section{Synthesis of 4-methyl-7-ethyl coumarin and} 1-amino-4-methyl-7-ethyl-1H-quinoline-2one $(L 1 \& L 2)$ :

Titled compounds were synthesized according to literature [10]. Their physical properties are listed in Table 1.

Synthesis of cyanoacetohydrazide $(\mathrm{L3})^{[11]}$ :

Titled compound was synthesized according to literature [11]. The physical properties are listed in Table 1 .

\section{Synthesis of 2-Cyano-N-(7-ethyl-4-methyl-2-} oxo-2H-quinolin-1-yl)-acetamide L4:

Titled compound was synthesized according to the two different ways:

\section{Method 1}

To a solution of compound L1 $(2.5 \mathrm{gm}$, 0.0131 mole) in $25 \mathrm{ml}$ DMF, cyanoacetohydrazide L3 (1.49 gm, 0.015 mole) was added, and refluxed for $24 \mathrm{~h}$. Then cooled, poured on ice/water, the resulting product was filtered off, then recrystallized from acetone : water (10:1). To give a white powder, yield of $75 \% \mathrm{R}_{\mathrm{f}}=0.5$. Physical properties of compound L4 are listed in Table 1.

\section{Method 2}

To a solution of compound L2 $(2.5 \mathrm{gm}$, $0.0131 \mathrm{~mole})$ in $25 \mathrm{ml}$ DMF, ethyl cyanoacetate (1.4 gm, 0.0131 mole) was added, and refluxed for $10 \mathrm{~h}$. Then the resulting solution was cooled, poured on ice water. The formed solid was filtered off, and recrystallized from acetone: water the physical properties are listed in Table 1.

\section{Synthesis of 7-Ethyl-4-methyl-1-[(arylidene)- amino]-1H-quinolin-2-one (L5-L8):}

A mixture of cinnamaldehyde/ salicyladehyde/4-methylbenzaldehyde and 4nitrobenzaldehyde $(0.015 \mathrm{~mole}) \quad$ and compound (L2) (0.015mole) in absolute ethanol $(25 \mathrm{ml})$ in the presence of (4 drops) of glacial acetic acid was refluxed for (8-10h.). The progress of the reaction was monitored by T.L.C hexane: ethylacetate (7:3) after complete the period of time, the mixture was cooled and poured into ice/cold water $(2 \mathrm{~g})$. The precipitated compounds were filtered off, and recrystallized from suitable solvents.

The physical properties of compounds [L5-L8] are listed in Table 1.

\section{Synthesis of (Chloro-p-tolyl-methyl)-(7- ethyl-4-methyl-2-oxo-2H-quinolin-1-yl)- carbamic acid L9:}

To a solution of appropriate Schiff base derivative (L7) (0.013 mole) in dioxane (50 $\mathrm{ml}$.), mono chloroacetic acid $((2,2),(1)) \mathrm{ml}$, 0.013 mole) was added. The mixture was refluxed for (13 hrs.), then cooled, the formed precipitate was filtered off, and recrystallized from Acetone: water as solvent. The physical properties of compound (L9) are listed in Table 1.

\section{Synthesis of 7-Ethyl-4-methyl-1-prop-2- ynylamino-1H-quinolin-2-oneL10:}

A solution of compound L2 (0.01 mole, 2 g) in alcoholic potassium hydroxide (4M) was refluxed for $(0.5 \mathrm{~h})$, then $(0.01$ mole, $0.86 \mathrm{ml})$ of propargyl bromide was added, and refluxed for $3 \mathrm{~h}$. After cooling the mixture, the solid product was filtered off, and recrystallized from Ethanol: $\mathrm{H}_{2} \mathrm{O}$ (10:1). The physical properties are listed in Table 1.

\section{Results and Discussions}

The condensation of ethyl acetoacetate with an equimolar amount of m-methyl phenol in the presence of conc. sulfuric acid under Pechemann condensation reaction 
produced coumarin derivative (L1). The substitution of phenol at the meta position with electron donating groups $\left(-\mathrm{C}_{2} \mathrm{H}_{5}\right.$, $)$ cause an increase in the reactivity of the carbon at the ortho position to the hydroxyl group and at para position of the substituent

The FTIR spectrum of compound (L1) showed the appearance of characteristic strong absorption band at $(1728) \mathrm{cm}^{-1}$ due to $(\mathrm{C}=\mathrm{O})$ band of the lactone ring. Table2 [12]

The ${ }^{1} \mathrm{H}-\mathrm{NMR}$ spectrum of compound (L1) showed the proton a signal due to two groups of $\mathrm{CH}_{3}$ were recorded at 1.2 and 2.6 ppm,a signal at $2.8 \mathrm{ppm}$ due to $\mathrm{CH}_{2}$ and signals at 7.3-7.8 ppm due to three aromatic protons and singlet signal at $6.3 \mathrm{ppm}$ for one proton of the lactone ring Table 3 Figure 1

While the ${ }^{13} \mathrm{C}$-NMR spectrum for the same compound showed signals at 15.1, 18 and 27.9 ppm for two groups of $\mathrm{CH}_{3}$, and $\mathrm{CH}_{2}$ the signals at $113.3,115.2,117.3,124.2$, $125.1,148.8,153.2$ and $153.9 \mathrm{ppm}$ due to aromatic carbons and $159.9 \mathrm{ppm}$ for carbonyl carbon (see Table 4 and Figure 2).

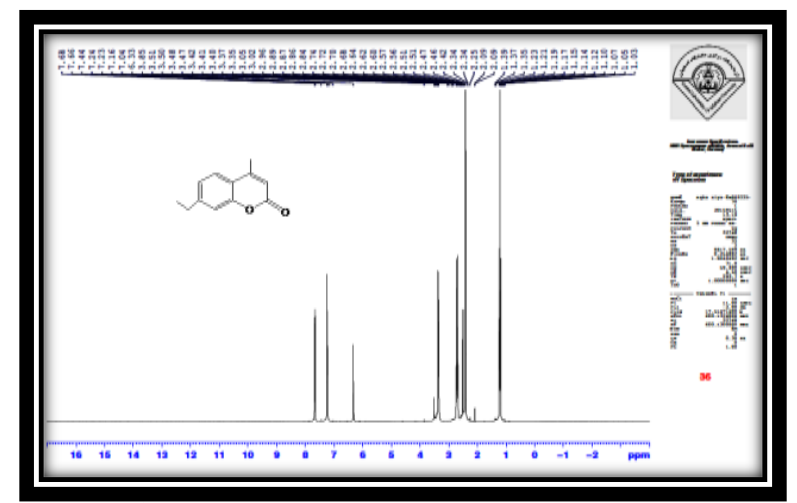

Fig.(1) ${ }^{1}$ HNMR spectrum for compound [L1].

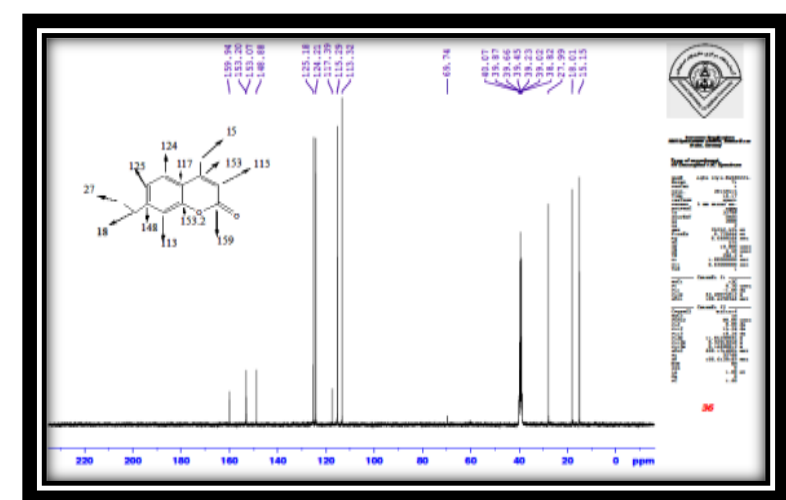

Fig.(2) ${ }^{13}$ CNMR spectrum for compound [L1].

The FTIR spectrum of compound (L2) showed the appearance of characteristic absorption bands at (3267) and (3198) $\mathrm{cm}^{-1}$ which belonging to asymmetric and symmetric to the $\mathrm{NH}_{2}$ and band at (1664) $\mathrm{cm}^{-1}$ due to the lactam group $v \mathrm{C}=\mathrm{O}$. See Table 2.

The ${ }^{1} \mathrm{H}-\mathrm{NMR}$ spectrum of compound (L2) showed triplet signal at $1.1 \mathrm{ppm}$ for three protons of methyl groups $\left(\mathrm{CH}_{2}-\mathrm{C}_{3}\right)$, singlet signal at $2.7 \mathrm{ppm}$ for methyl groups of lactam ring $\left(\mathrm{Ar}-\mathrm{CH}_{3}\right)$,quartet signal at $2.5 \mathrm{ppm}$ for methylene group $\left(\mathrm{CH}_{2}\right)$, singlet signal at 5.9 ppm for two protons of $\left(\mathrm{NH}_{2}\right)$, and signals at 6.6-9.3 ppm for four aromatic protons. See Table 3 Figure 3.

${ }^{13} \mathrm{C}-\mathrm{NMR}$ spectrum of compound (L2) showed signals at 15, 24.7 and $27.65 \mathrm{ppm}$ for aliphatic protons and showed signals at 113 , $115.5,115.6,118.1,125.7,126.9,143.7$ and $155.3 \mathrm{ppm}$ for aromatic carbons, and 155.5 ppm for carbonyl group (see Table 4 and Figure 4).

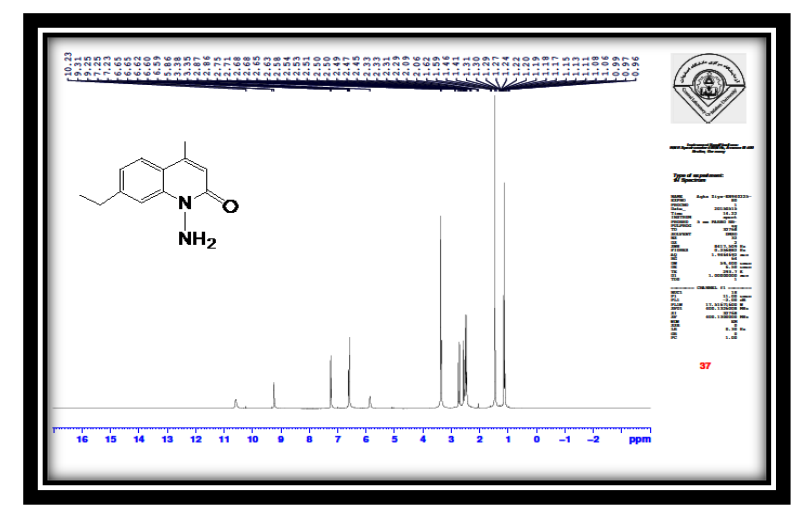

Fig.(3) ${ }^{I}$ HNMR spectrum for compound [L2].

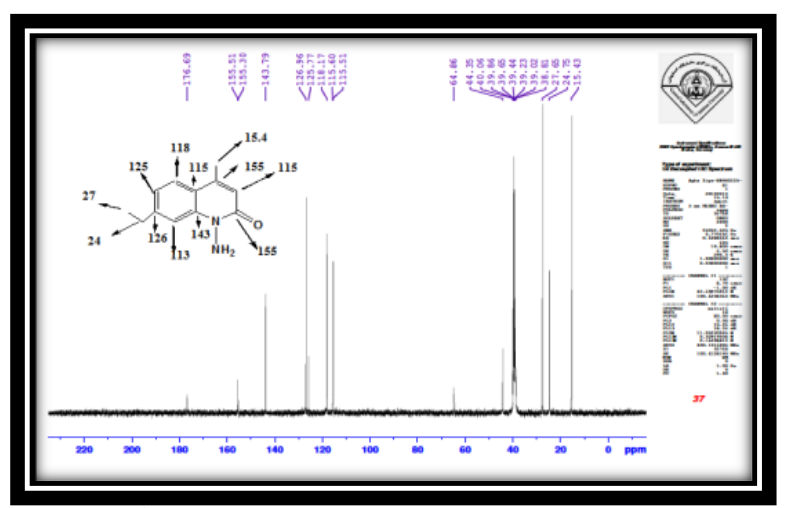

Fig.(4) ${ }^{13}$ CNMR spectrum for compound [L2].

Acid hydrazid compound L3 was prepared via treatment of ethylcyanoacetate with excess of hydrazine hydrate $(80 \%)$ in absolute ethanol was reacted with coumarin (L1) to produce compound (L4). 
The FTIR spectrum of compound L4 showed absence of characteristic absorption bands for $v \mathrm{NH}_{2}$ and the appearance of the characteristic absorption band at $3214 \mathrm{~cm}^{-1}$ which belong to the $v \mathrm{NH}$ and other bands at $1726 \mathrm{~cm}^{-1}$ and $1678 \mathrm{~cm}^{-1}$ due to carbonyl lactam group and carbonyl amide [L3] $v(\mathrm{C}=\mathrm{O})$ (Table 2).

The ${ }^{1}$ HNMR spectrum of compound [L4] showed singlet signal at $3.36 \mathrm{ppm}$ due to two protons of $\mathrm{CH}_{2}$ and $6.35-7.77 \mathrm{ppm}$ due to aromatic protons and the proton of $\mathrm{NH}$ group (Table 3 and Figure 5).

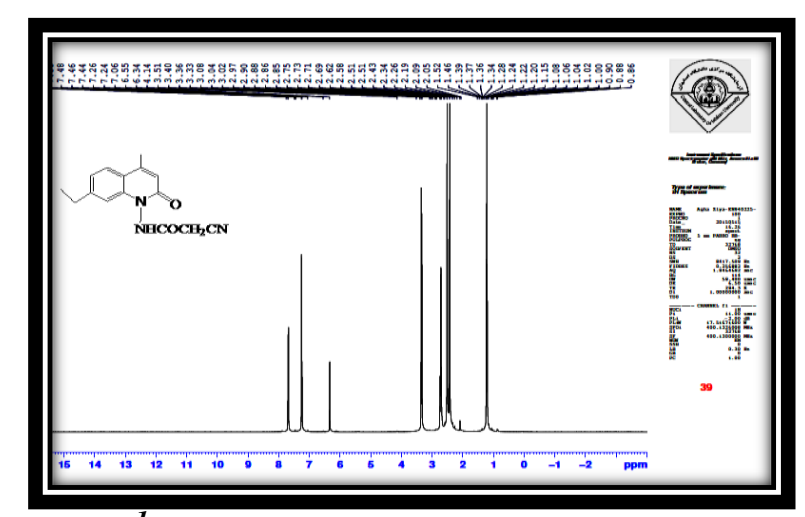

Fig.(5) ${ }^{1}$ HNMR spectrum for compound [L4].

The synthesized amino compound (L2) was treated with different substituted aromatic aldehydes led to the formation of Schiff bases of the title compounds (L5-L8)

The FTIR spectra of compounds (L5-L8) were confirmed by the absence of absorption band for $\left(\mathrm{vNH}_{2}\right)$ and appearance of new absorption bands at (1608-1654) $\mathrm{cm}^{-1}$ due to $(v \mathrm{C}=\mathrm{N})$ starching the spectrum showed other bands at (1666-1670) $\mathrm{cm}^{-1}$ and (1633-1573) $\mathrm{cm}^{-1}$ due to $v(\mathrm{C}=\mathrm{O})$ amide of lactam and $v(C=C)$ respectively. The presence of $\mathrm{OH}$ group in ortho position to the imine group involved in intramolecular hydrogen bonding for compound L6 gave the $(\mathrm{OH})$ as shallow and not defined as shown in figure 6 [14].

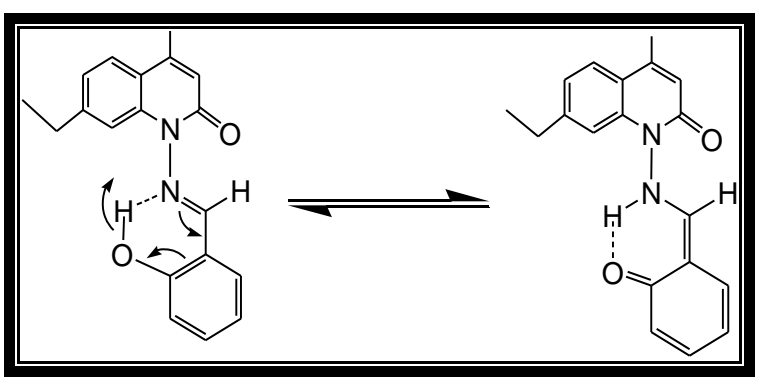

Fig.(6)

The FTIR spectral data of compounds (L5-L8) were listed in Table 2 and Figure 7.

${ }^{1}$ HNMR spectrum of compound (L7) showed signals at (7.31-8.9) ppm for aromatic protons of aryl groups and benzylic proton and singlet signal at 2.2ppm for three protons of tolene group $\left(\mathrm{CH}_{3}\right)$ (see Table 3 and Figure 7).

${ }^{1} \mathrm{HNMR}$ spectrum of compound (L8) showed a new signal observed at $8.8 \mathrm{ppm}$ integrating for $(\mathrm{CH}=\mathrm{N})$, signals at $(8.27-8.9)$ ppm for aromatic protons of aryl groups (Table 3 and Figure 8).

The reaction between the Schiff bases derivative L7 with chloroacetic acid in dioxane gave compound L9 the mechanism of this reaction involved nucleophilic attack of nitrogen on the carbon bearing chloro atom and the chloride added to the other side on the carbon of the imine group as shown The FTIR spectrum of compound L9 showed disappearance of $v(\mathrm{C}=\mathrm{N})$ and appearance of the new absorption broad band at 3000-3400 $\mathrm{cm}^{-1}$ due to $(-\mathrm{OH})$ of carboxylic acid group Table 2.

Synthesis of compound L10 was performed by the reaction of 1-amino-4methyl-7-ethyl-1H-quinolin-2-one with propargyl bromide under refluxing condition in the presence of potassium hydroxide.

The FTIR spectrum of the synthesized compound L10 showed an absorption band at $3449 \mathrm{~cm}^{-1}$ for $(\mathrm{vNH}), 3354$ for $(\mathrm{v} \mathrm{H}-\mathrm{C}=)$, $2298 \mathrm{~cm}^{-1}$ for $(v C=C)$, and $1655 \mathrm{~cm}^{-1}$ for $(v$ $\mathrm{C}=\mathrm{O}$ ) of lactam ring. All spectral data of synthesized compounds (L10) were listed in Table 2. 
Special Issus: $1^{\text {st }}$ Scientific International Conference, College of Science, Al-Nahrain University, 21-22/11/2017, Part II, pp.30-37

Table 1: Physical properties of synthesized compounds (L1-L10)

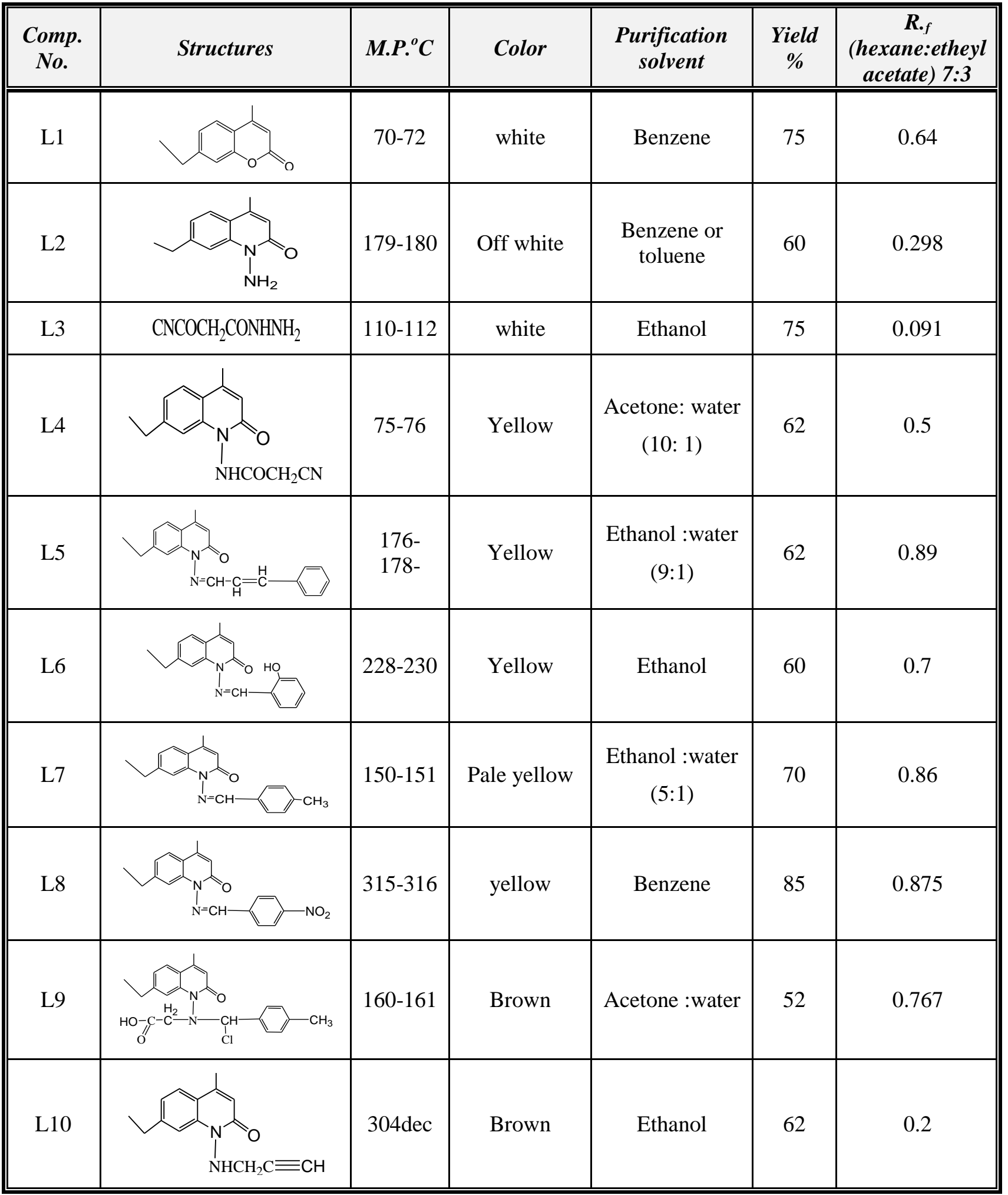


Table 2: FTIR data of synthesized compounds (L1-L10)

\begin{tabular}{|c|c|c|c|c|c|c|c|c|}
\hline $\begin{array}{c}\text { Comp. } \\
\text { No. }\end{array}$ & $\mathrm{vNH}_{2}$ & $\begin{array}{c}\boldsymbol{c} C H \\
\text { Aromatic }\end{array}$ & $\begin{array}{c}\boldsymbol{v C H} \\
\text { Aliphatic }\end{array}$ & $v C=O$ & $v C=N$ & $v C=C A r$ & $C-N$ & Other bands \\
\hline L1 & - & 3059 & $\begin{array}{l}2960 \\
2930 \\
\end{array}$ & 1728 & 1618 & & - & $\begin{array}{c}\mathrm{C}-\mathrm{O}-\mathrm{C} \\
1259\end{array}$ \\
\hline L2 & $\begin{array}{l}3267 \\
3198\end{array}$ & 3053 & $2991 ; 2961$ & 1664 & & 1622 & 1346 & \\
\hline L3 & $\begin{array}{c}3344 \\
3281, \\
3179 \\
\end{array}$ & 3056 & $2978 ; 2930$ & 1684 & & 1618 & 1388 & v $\mathrm{C} \equiv \mathrm{N} 2261$ \\
\hline $\mathrm{L} 4$ & 3214 & 3057 & $2964 ; 2872$ & $\begin{array}{l}1726, \\
1678\end{array}$ & & $\begin{array}{c}1616 ; 158 \\
0 \\
\end{array}$ & 1384 & 2344 \\
\hline L5 & - & 3028 & 2926 & 1666 & 1654 & 1633 & 1363 & - \\
\hline L6 & - & $\begin{array}{l}3101 \\
3043 \\
\end{array}$ & $\begin{array}{l}2849 \\
2900 \\
\end{array}$ & 1623 & 1623 & 1573 & 1392 & - \\
\hline L7 & - & 3030 & $\begin{array}{l}2925 \\
2918 \\
2853\end{array}$ & 1623 & 1608 & 1609 & 1321 & $p$-sub 818 \\
\hline L8 & - & 3100 & $\begin{array}{l}2843 ; \\
2915\end{array}$ & 1635 & 1630 & 1596 & 1380 & $\begin{array}{c}\mathrm{NO}_{2} 1519 \& 1346 \\
p \text {-sub } 839\end{array}$ \\
\hline L9 & - & 3010 & $\begin{array}{l}2977 \\
2883\end{array}$ & $\begin{array}{c}1751 \\
\text { acid } \\
1640 \\
\text { lactam } \\
\end{array}$ & & 1558 & & $\begin{array}{c}851 \text { v C-Cl } \\
3000-2400 v(\mathrm{OH})\end{array}$ \\
\hline L10 & 3449 & & 2980 & 1655 & & 1560 & 1369 & $\begin{array}{c}3354 v(\equiv \mathrm{CH}) \\
2298 v \mathrm{C} \equiv \mathrm{C}\end{array}$ \\
\hline
\end{tabular}

Table 3: ${ }^{1} H$-NMR of some synthesized compounds (L1, L2, L4, L7 and L8)

\begin{tabular}{|c|c|}
\hline $\begin{array}{l}\text { Comp. } \\
\text { No. }\end{array}$ & ${ }^{1} \mathrm{H}-\mathrm{NMR}(\mathrm{ppm})$ \\
\hline L1 & 1.2(t,3H, $\left.\mathrm{CH}_{3}\right), 2.6\left(\mathrm{~s}, 3 \mathrm{H}, \mathrm{CH}_{3}\right), 2.8\left(\mathrm{q}, 2 \mathrm{H}, \mathrm{CH}_{2}\right), 6.3(\mathrm{~s}, 1 \mathrm{H}, \mathrm{H}$ lactone ring $), 7.3-7.8(\mathrm{~m}, 3 \mathrm{H}, \mathrm{Ar}-\mathrm{H})$ \\
\hline $\mathrm{L} 2$ & $1.1\left(\mathrm{t}, 3 \mathrm{H}, \mathrm{CH}_{3}\right), 2.5\left(\mathrm{q}, 2 \mathrm{H}, \mathrm{CH}_{2}\right), 2.7\left(\mathrm{~s}, 3 \mathrm{H}, \mathrm{Ar}-\mathrm{CH}_{3}\right), 5.9\left(\mathrm{~s}, 2 \mathrm{H}, \mathrm{NH}_{2}\right), 6.6-9.3(\mathrm{~m}, 4 \mathrm{H}, \mathrm{Ar}-\mathrm{H})$ \\
\hline L4 & $6.35-7.77(\mathrm{~m}, 4 \mathrm{H} \mathrm{Ar}-\mathrm{H}$ and $\mathrm{NH}), 1.22\left(\mathrm{t}, 3 \mathrm{H}, \mathrm{CH}_{3}\right), 2.73\left(\mathrm{q}, 2 \mathrm{H}, \mathrm{CH}_{2}\right), 2.4\left(\mathrm{~s}, 3 \mathrm{H}, \mathrm{CH}_{3}\right), 3.36\left(\mathrm{~s}, 2 \mathrm{H}, \mathrm{CH}_{2}\right)$ \\
\hline L7 & $\begin{array}{c}1.2\left(\mathrm{t}, 3 \mathrm{H}, \mathrm{CH}_{3}\right), 2.2\left(\mathrm{~s}, 3 \mathrm{H}, \mathrm{CH}_{3}\right), 2.4\left(\mathrm{~s}, 3 \mathrm{H}, \mathrm{CH}_{3}\right), 2.67\left(\mathrm{q}, 2 \mathrm{H}, \mathrm{CH}_{2}\right) 7.31-8.90(\mathrm{~m}, 8 \mathrm{H}, \mathrm{Ar}-\mathrm{H}) \text { and } \\
\text { benzylic proton }\end{array}$ \\
\hline L8 & $1.15\left(\mathrm{t}, 3 \mathrm{H}, \mathrm{CH}_{3}\right), 2.51\left(\mathrm{~s}, 3 \mathrm{H}, \mathrm{CH}_{3}\right), 2.57\left(\mathrm{q}, 2 \mathrm{H}, \mathrm{CH}_{2}\right) 8.27-8.90(\mathrm{~m}, \mathrm{Ar}-\mathrm{H}), 8.8(\mathrm{~s}, 1 \mathrm{H}, \mathrm{N}=\mathrm{CH})$ \\
\hline
\end{tabular}

Table 4: ${ }^{13} C$-NMR for some preparing compounds (L1 \& L2)

\begin{tabular}{|c|c|}
\hline Comp.No. & ${ }^{13}$ C-NMR $(p p m)$ \\
\hline \hline L1 & $15.1,18.0,27.9,113,115.2,117.3,124.2,125.1,148.8,153.2,153.9,159.9$ \\
\hline L2 & $15.4,24.7,27.6,113,115.5,115.6,118.1,125.7,126.9,143.7,155.3,155.5$ \\
\hline
\end{tabular}




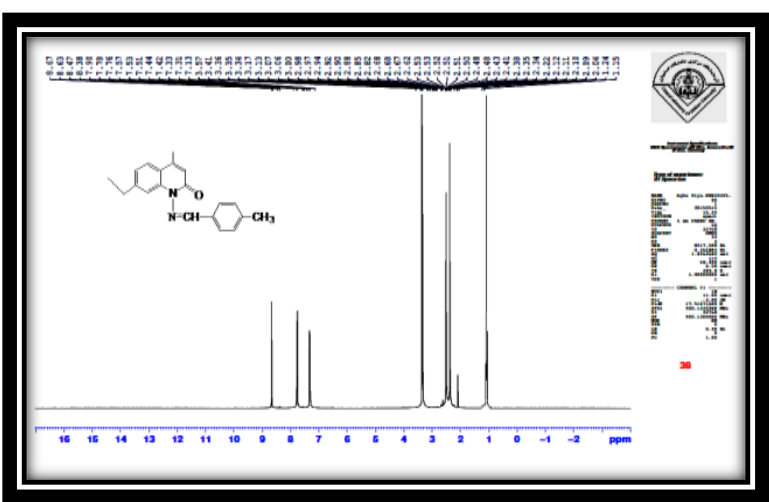

Fig.(7) ${ }^{1}$ HNMR spectrum for compound [L7].

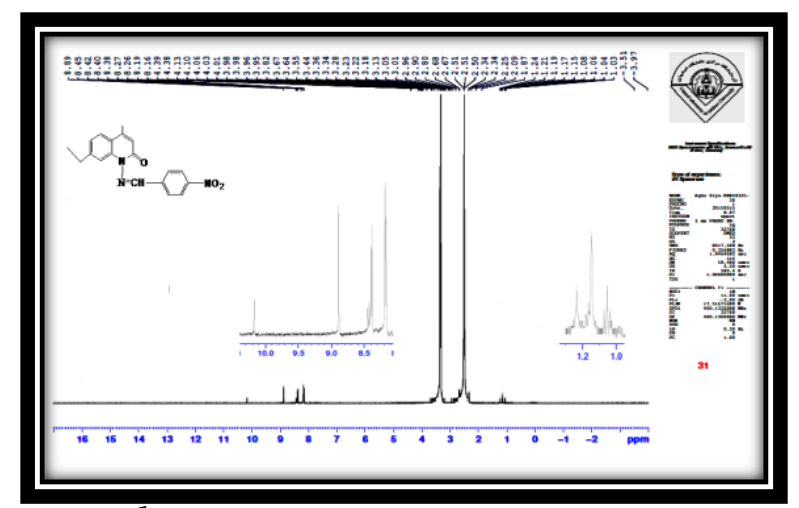

Fig. (8) ${ }^{1}$ HNMR spectrum for compound [L8].

\section{Conclusion}

New N-heteroaromatic compounds were synthesized starting from 7-ethyl-4-methyl-2coumarin in a good yield the isolated compounds were characterized by FT-IR, ${ }^{1} \mathrm{H}$ NMR, ${ }^{13}$ C-NMR spectra and by measuring some of their physical properties

\section{References}

[1] Redha I. Al-Bayati, Mohammed R. Ahamad, Luma S. Ahamed, Synthesis and Biological Activity Investigation of Some Quinoline-2-One Derivatives American Journal of Organic Chemistry 5(4): 125-135 (2015).

[2] Ishar MPS, Singh G, Singh S, Sreenivasan KK, Singh G. Design, synthesis and evaluation of novel 6chloro-/fluorochromone derivatives as potential topoisomerase inhibitor anticancer agents. Bioorg Med Chem Lett.; 16(5): 1366-1370 ( 2006).

[3] Rodrigues-Silva C, Maniero MG, Peres MS, Guimarães JR. Ocorrência degradação de quinolonas por processos oxidativos avançados. Quím. Nova; 37(5): 1-18 (2014).
[4] Silvia M. Uriarte, Robert E. Molestina, Richard D. Miller, Jorge Bernabo, Alicia Farinati, Kumiko Eiguchi, Julio A. Ramirez and James T. Summersgill Effects of Fluoroquinolones on the Migration of Human Phagocytes through Chlamydia pneumoniae-Infected and Tumor Necrosis Factor Alpha-Stimulated Endothelial Cells anti-microbial agents and chemotherapy, July. 2538-2543 (2004).

[5] Beteck RM, Smit FJ, Haynes RK, Da DD. Recent progress in the development of antimalarial quinolones. Malaria Journal, 13: 339 (2014).

[6] Alan M. Sugar, Xiu-Ping Liu and RongJin Chen Effectiveness of Quinolone Antibiotics in Modulating the Effects of Antifungal Drugs, Antimicrobial Agents and Chemo-therapy 41(11) 2518-252, 1 (1997).

[7] Mohammad Asif, Asif Husain, Aftab Ahmad, Shah Alam Khan, Mohd Rashid, Karun Arora, Dherya Bahl and Farah Iram. An overview on antitubercular activities of fluoroquinolones and other related analogues European Journal of Experimental Biology, 5(2): 96-109, (2015).

[8] Pudlo M, Luzet V, Ismaili L, Tomassoli I, Lutzelet A, Refouvelet B. Quinolonebenzylpiperidine derivatives as novel acetylcholinesterase inhibitor and antioxidant hybrids for Alzheimer Disease, Bioorg Med Chem,; 22(8): 2496-2507, (2014).

[9] Elizabeth Nenortas, Tomasz Kulikowicz, Christian Burri and Theresa A. Shapiro Antitrypanosomal Activities of Fluoroquinolones with Pyrrolidinyl Substitutions Antimicrobial Agents and Chemotherapy, 47(9), 3015-3017, (2003).

[10] Redha I. Al-Bayati, Mohammed R. Ahamad, Luma S. Ahamed, Synthesis and Biological Activity Investigation of Some Quinoline-2-One Derivatives American Journal of Organic Chemistry, 5(4): 125-135, 2015.

[11] Samir, B., Abd El-Gaber T., and Ahmed A. Fadda Utility of cyanoacetic acid hydrazide in heterocyclic synthesis Arkivoc (ix) 113-156 (2006). 
[12]Raj, R.K. Gunasekaran, S. Gnanasambandan, T. and Seshadri, S. Structural, Spectroscopic (FT-IR, FTRaman \& UV-Vis) and theoretical studies of 4,6-Dichloro-3-formyl coumarin Int. J. Curr. Res. Aca. Rev. 3(3), 130-149, (2015).

[13]Luma S.Ahamed Synthesis of New Polyester-Amides from polyvinyl Alcohol and Convert Some of Them to Polyester-Imide Journal of Al-Nahrain University- Science 14(2), 29-42, 2011.

[14]Raafat, M.I., Abdalla M. Khedr and Helen R. HNMR, IR and UV/VIS Spectroscopic Studies of Some Schiff Bases Derived From 2Aminobenzothiazole and 2-Amino-3hydroxypyridine J. Chin. Chem. Soc. 55, 875-884, (2008). 